\title{
Dimensions of the 2020 wildfire catastrophe in the Pantanal wetland: the case of the municipality of Poconé, Mato Grosso, Brazil
}

Dimensões da catástrofe dos incêndlios de 2020 no Pantanal: o caso do município de Poconé, Mato Grosso, Brasil

Dimensiones de la catástrofe del incendio del Pantanal de 2020: el caso del municipio de Poconé, Mato Grosso, Brasil

\author{
Vinícius de Freitas Silgueiro \\ ORCID: https://orcid.org/0000-0002-0185-7386 \\ Instituto Centro de Vida, Brazil \\ E-mail: vinicius.silgueiro@icv.org.br \\ Carolina Ortiz Costa Franco de Souza \\ ORCID: https://orcid.org/0000-0002-4900-2504 \\ Universidade de São Paulo, Brazil \\ E-mail: costa_cor@yahoo.com.br \\ Eriberto Oliveira Muller \\ ORCID: https://orcid.org/0000-0003-0304-9101 \\ Universidade do Estado de Mato Grosso, Brazil \\ E-mail: Eriberto.muller@unemat.br \\ Carolina Joana da Silva \\ ORCID: https://orcid.org/0000-0003-0517-1661 \\ Universidade do Estado de Mato Grosso, Brazil \\ E-mail: carolina.silva@unemat.br
}

\begin{abstract}
In 2020, a total of 3.9 million hectares were burned in the Pantanal biome, which represents approximately $30 \%$ of its total area. Of the three existing biomes in the state of Mato Grosso, the Pantanal was the most impacted and, among all the municipalities in Mato Grosso, Poconé had the largest burned area. We aimed to characterize the areas affected by fires in the municipality of Poconé in 2020 to support prevention and adaptation actions in future scenarios. For this, we used the mapping of areas affected by fires made from the detections of active fire collected by the Visible Infrared Imaging Radiometer Suite (VIIRS) sensor and available by the Global Fire Emissions Database (GFED). The results showed that a total of 869,170 hectares were burned in Poconé in 2020. Of this total, 97.3\% were in natural areas, viz. forest formations (37\%), savanna (2.8\%), grassland formations $(23.4 \%)$, wetlands $(29.7 \%)$, and vegetation in dried-up rivers and lakes $(4.4 \%)$. Concerning land categories, almost half of the fires occurred in private rural properties registered in the Rural Environmental Registry (CAR). In this scenario, we highlighted the importance of monitoring fires and holding those responsible for them accountable. It is also important to implement preventive actions in synergy with managers and local communities as a way of adapting to the climate crisis, intense drought, and less water surface available in the region, which increases the risk and damage of fires.
\end{abstract}

Keywords: Burned areas; Fire damage; Land use and cover; Climate crisis; Adaptation.

\section{Resumo}

Em 2020, um total de 3,9 milhões de hectares foram atingidos por incêndios no bioma Pantanal, o que representa aproximadamente $30 \%$ de sua área total. Dos três biomas existentes no estado de Mato Grosso, o Pantanal foi o mais afetado e entre todos os municípios mato-grossenses, Poconé foi o que teve maior área queimada. Nós buscamos caracterizar as áreas atingidas pelos incêndios no município de Poconé no ano de 2020, para subsidiar ações de prevenção e adaptação em cenários futuros. Para isso utilizamos o mapeamento das áreas atingidas por incêndios elaborado a partir das detecções de focos de calor do sensor Visible Infrared Imaging Radiometer Suite (VIIRS) e disponibilizado pelo Global Fire Emissions Database (GFED). Os resultados mostraram que um total de 869.170 hectares foram atingidos por incêndios em Poconé em 2020. Desse total queimado, 97,3\% foram áreas de formação natural, sendo elas formações florestais (37\%), savânicas (2,8\%), campestres (23,4\%), campos alagados e áreas pantanosas $(29,7 \%)$ e de vegetação em cursos d'água e lagos que secaram (4,4\%). Em relação às categorias fundiárias, quase metade dos incêndios ocorreu em imóveis rurais privados inscritos no Cadastro Ambiental Rural (CAR). Diante desse cenário, destacamos as necessidades de fiscalizar e responsabilizar os causadores dos incêndios. Assim como implementar ações preventivas em total sinergia com os gestores e comunidades locais, como forma de adaptação 
frente a crise climática, secas intensas e menor superfície de água disponível na região, que aumentam o risco e dano dos incêndios.

Palavras-chave: Áreas queimadas; Danos do fogo; Uso e cobertura da terra; Crise climática; Adaptação.

\section{Resumen}

En 2020, un total de 3,9 millones de hectáreas se vieron afectadas por incendios en el bioma del Pantanal, lo que representa aproximadamente $30 \%$ de su superficie total. De los tres biomas existentes en el estado de Mato Grosso, el Pantanal fue el más afectado y entre todos los municipios de Mato Grosso, Poconé tuvo la mayor superficie quemada. Buscamos caracterizar las áreas afectadas por incendios en el municipio de Poconé en 2020, para apoyar acciones de prevención y adaptación en escenarios futuros. Para ello, utilizamos el mapeo de áreas afectadas por incendios elaborado a partir de la detección de puntos calientes por el sensor Visible Infrared Imaging Radiometer Suite (VIIRS) y disponible por Global Fire Emissitions Database (GFED). Los resultados arrojaron que un total de 869.170 hectáreas fueron afectadas por incendios en Poconé en 2020. De este total quemado, 97.3\% fueron áreas de formación natural, siendo formaciones forestales (37\%), sabanas (2.8\%), campos (23.4\%), campos inundados y zonas pantanosas (29.7\%) y vegetación en cursos de agua y lagos que se secaron (4.4\%). En relación a las categorías de tierra, casi la mitad de los incendios ocurrieron en propiedades rurales privadas inscritas en el Registro Ambiental Rural (CAR). Ante este escenario, destacamos la necesidad de monitorear y responsabilizar a los causantes de los incendios, así como realizar acciones preventivas a nivel local, encaminadas a adaptarse a la crisis climática, las sequías intensas y la menor disponibilidad de agua superficial en la región, que aumentan el riesgo y daño de incendios.

Palabras clave: Áreas quemadas; Daño por fuego; Uso y cobertura de la tierra; Crisis climática; Adaptación.

\section{Introduction}

Brazil harbors six biomes, among which Pantanal is highlighted because it is considered a national heritage by the Constitution of 1988 and world heritage and biosphere reserve by UNESCO, with four Ramsar sites. Pantanal is spread across Paraguay, Bolivia, and Brazil, in the states of Mato Grosso and Mato Grosso do Sul. The state of Mato Grosso includes three biomes: Amazonia (57\%), Cerrado (37\%) and Pantanal (6\%) (IBGE, 2019). In 2020, the whole state was strongly affected by fires. In the whole Pantanal biome, a total of 3.9 million hectares were burned (Tomas et al., 2021), which represents almost $30 \%$ of its total area. According to ICV (2020), in Mato Grosso, proportionally, the Pantanal was the most impacted biome and, among all municipalities of Mato Grosso, Poconé was the most affected.

The main causes of the large fires are climate change, changes in land use, and bad environmental governance (Libonati et al., 2021; Silva et al., 2021). The extended drought in 2019 and 2020 is one of the factors that increased, even more, the risk and damage of forest fires (Pivello et al., 2021). As argued by Pletsch et al. (2021), the weakening of the monitoring organs and environmental supervision, which happened through funding cut or reduction, also contributed to this scenario, as this certainly compromised the capacity of fighting and preventing fires in this region.

The consequences of fires are immeasurable and go from impacts on the biota to economic loss on husbandry, fishing, and biodiversity-supported ecotourism. Tomas et al. (2021) calculated that 17 million vertebrates died as a direct consequence of the fires in the whole Pantanal biome in 2020. In that same year, the Encontro das Águas State Park, which is considered the largest jaguar refuge in the world (Tortato et al., 2017), had more than $90 \%$ of its area affected by fire (ICV, 2020).

The use of fire in burnings is a technique for agricultural management due to its high efficacy in removing competing plants, pests, and residues of the conversion of land cover, together with a considerable fertilizing power of the ashes (FonsecaMorello et al., 2017; Burin \& Fuentes, 2015). According to the Brazilian Forest Code, controlled burnings for agricultural use are allowed through a permit of the environmental agency and, in other forms, as practices for preventing and combating fires, as well as in subsistence agriculture practiced by traditional and indigenous populations (BRASIL, 2012). Wildfires can be considered externalities of burnings (Fonseca-Morello et al., 2017) and occur when a fire is unplanned or becomes uncontrolled, reaching any large-sized vegetation (Tedim \& Leone, 2020; Aragão et al., 2018).

In Pantanal, the distribution and diversity of native plant species vary within and between the different habitats arranged along the flooding gradient, which includes non-floodable, seasonally flooded, and permanently flooded areas 
(Rebellato \& Nunes da Cunha, 2005). Due to this richness of different vegetation types, we adopted the term wildfire in this work to describe any unplanned and uncontrolled fire that starts in the native vegetation. According to Tedim and Leone (2020), this term predominates in North America and is being increasingly used everywhere. In Europe and Australia, the terms bushfire and forest fire are used, respectively. However, the phenomenon of fire as combustion of vegetation in an open environment follows the same physical and chemical laws everywhere (Tedim \& Leone, 2020).

The fire detections spots obtained through different sensors are the most common data and with the longest historical series to represent burnings and active wildfires. However, the active fire detection by the Visible Infrared Imaging Radiometer Suite (VIIRS) sensor has been highlighted to map the area burned in almost real time (Santos et al., 2021; Oliva \& Schroeder, 2015).

Recently, Andela et al. (2019) developed the algorithm Global Fire Atlas, which can map areas affected by fires individually on any day and in the whole region with available VIIRS data, where information about land cover in the burned area is combined with characteristics of the fire event, which results in a unique signature for each type of wildfire. This innovative mapping has been allowing new ways of representing the areas impacted by wildfires, as well as understanding the dynamics and measuring the impacts of the fire. Its adoption has been showing huge potential of making the prevention and combat of large wildfires more effective.

In the face of the current scenario, as recommended by the Sustainable Development Goals (SDG) of the United Nations (UN) in Goal 13, regarding climate change, the planning, strategies, and adaptations are part of the concepts and practices to be adopted. Therefore, we tried to characterize the areas affected by the wildfires in the municipality of Poconé in 2020 to support actions of planning, prevention, and adaptation in future scenarios.

\section{Methodology}

\subsection{Study Area}

The municipality of Poconé is located in the south of the state of Mato Grosso, in the Paraguay River basin, which belongs to the large Platine basin (Figure 1). It has a total area of 1,731,507 hectares and $81 \%$ of its area is inserted in the Pantanal biome, with the remaining 19\% in the Cerrado biome (IBGE, 2019). 
Figure 1. Location of the study area in South America, Brazil, and the Pantanal biome.
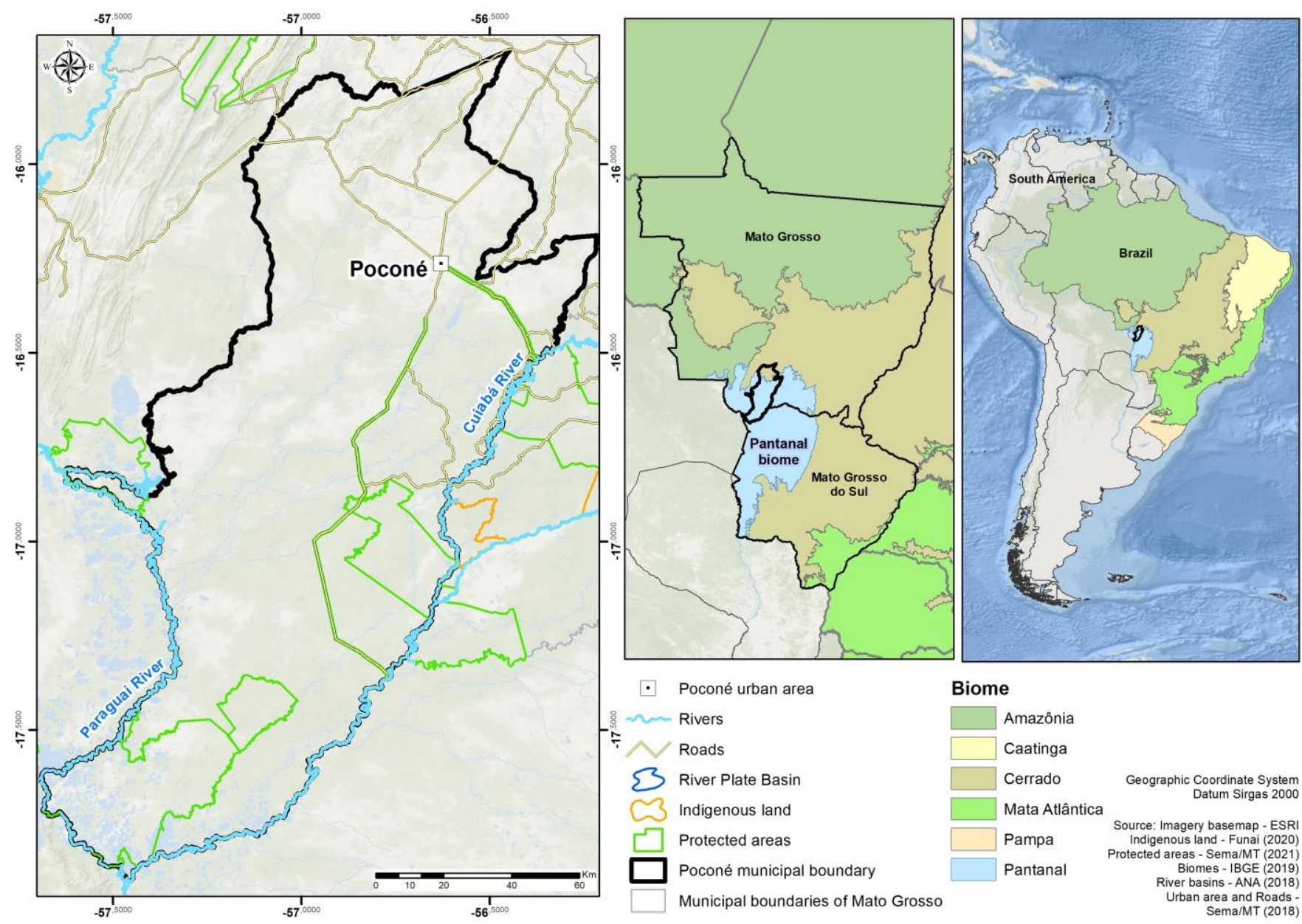

Source: Own work (2021).

The municipality is known as the entrance gate for Mato Grosso's Pantanal. The Transpantaneira road begins in its urban area and connects the city of Poconé to Porto Jofre, by the Cuiabá River. Likewise, the MT-370 road provides access to Porto Cercado, by the Cuiabá River.

According to the Köppen classification, the climate of Poconé is of the AW type, hot and humid, with mean annual precipitation of $1,250 \mathrm{~mm}$ and mean annual temperature of $25.8{ }^{\circ} \mathrm{C}$, with two well-defined seasons: dry, from May to September, and rainy, from October to April (Rebellato \& Nunes da Cunha, 2005).

Poconé's hydrography consists of the Cuiabá, São Lourenço, and Paraguay rivers, which are the largest rivers bordering the municipality. The Paraguaizinho and Bento Gomes rivers are also important rivers of the local landscape, having a rich network of drainage channels (corixos) and ponds during the flooded period. Poconé lies mostly on the Pantanal's plains and has a water regime associated with the seasonal flood pulse, which consists of four phases as characterized by Da Silva and Esteves (1995): flooding, full flood, ebb, and drought.

According to the technical handbook of Brazilian vegetation (IBGE, 2012), the prevailing vegetation types in Poconé consist of forested savannas (cerradão), wooded savannas (cerrado) with or without gallery forests, grassy-woody savannas (wet grasslands), and park savannas (earth-mound grasslands) with or without gallery forests. Additionally, there are grassywoody steppe-savannas without palms and without gallery forests, forested steppe-savannas, and alluvial and lowland semidecidual season forests with emerging canopy. 


\subsection{Mapping the areas affected by wildfires}

The data of the areas affected by wildfires used in this study refer to the year 2020 and were obtained through the Global Fire Emissions Database (GFED). These data have been used to characterize the areas affected by fire (ICV, 2020; MapBiomas, 2020) and here we adopt them to understand the dimensions of wildfires for the municipality of Poconé, as a case study.

The possibility of developing the GFED platform started when a study by Oliva and Schroeder (2015) showed that the active fire detections by the Visible Infrared Imaging Radiometer Suite (VIIRS) can be used to map the area affected by wildfires in almost real time. The fire detections spots of the VIIRS sensor on the satellites Suomi-NPP and NOAA-20 have a spatial resolution of 375 meters and allow daily estimations of burned area with a spatial resolution of about 550 meters.

With this, Andela et al. (2019) developed the Global Fire Atlas algorithm, which allows mapping the areas affected by fire individually on any day and in the whole region with the available VIIRS data. In the mapping of each fire event, information of land cover (tree cover, biomass, and deforestation history) in each burned area is combined with characteristics of the wildfire (e.g., fire's radiating power, persistence, progression, and size), which results in a unique signature for each type of wildfire (Andela et al., 2019).

\subsection{Data processing and analysis}

Using the software ArcGIS (2020), we initially outlined the data for the municipality of Poconé. Later, we applied tools for the geographic processing of the data to classify the areas affected by fire according to biome and according to different land categories, viz., properties registered in the Rural Environmental Registry (Cadastro Ambiental Rural, CAR), unregistered areas, rural settlements, indigenous lands, conservation units, and urban areas.

For the analysis of land use and cover in the areas affected by fire, we evaluated both information in the data of the burned areas themselves and data from Collection 5 of MapBiomas from 2019, based on the methodology of Souza Jr. et al. (2020). In this classification of MapBiomas (2019), the following classes of land use and cover are listed for Poconé: natural formations (forests, savannas, grasslands, wetlands, rivers and lakes and other non-vegetated areas) and human formations (pasture, sugar cane, soybean, other temporary crops, planted forest, mining, and urban infrastructure).

The results were organized into tables, and, with the software ArcGIS, we produced maps to show the occurrence of the 2020 wildfires in the land categories and the different classes of land use and cover of the municipality of Poconé.

\section{Results}

\subsection{Biomes}

In $2020,869,170$ hectares in the municipality of Poconé were affected by wildfires, of which 854,686 hectares (98.3\%) were in areas of Pantanal and 14,484 hectares (1.7\%) were in areas of Cerrado.

\subsection{Land use and cover}

Data from mapping the areas affected by fire of the Global Fire Emissions Database pointed out that $76.6 \%$ of the burned areas were characterized as forest or understory. Other $6.5 \%$ of the burned areas had been recently deforested. Savannas and pastures made up $16.1 \%$ and $0.8 \%$ of small plantations and agriculture (Table 1). 
Table 1. Data of use and cover of the land affected by the wildfires in Poconé in 2020.

\begin{tabular}{ccc}
\hline Type of area affected by fire & Area (hectares) & $\%$ \\
\hline Savanna and pasture & 139,905 & 16.1 \\
Small clearing and agriculture & 7,232 & 0.8 \\
Forest or understory & 665,837 & 76.6 \\
Recent deforestation & 56,196 & 6.5 \\
Total & 869,170 & 100.00 \\
\hline
\end{tabular}

Source: Own work (2021).

When analyzing the data of MapBiomas to characterize the types of land use and cover in the areas affected by fire in Poconé, $97.3 \%$ of the burned area were natural areas, including forests (37\%), savannas (2,8\%), grasslands $(23,4 \%)$, wetlands $(29,7 \%)$ and vegetation in dried-out water bodies (4.4\%). The other $2.7 \%$ affected were pasture areas (Table 2 and Figure 2).

Table 2. Data of land use and cover affected by the wildfires in Poconé in 2020.

\begin{tabular}{ccc}
\hline Class of land use and cover & Area (hectares) & \% \\
\hline Not observed & 140 & 0.0 \\
Forest & 321,503 & 37.0 \\
Savanna & 24,360 & 2.8 \\
Planted forest & 0 & 0.0 \\
Flooded grassland and swamp area & 258,210 & 29.7 \\
Grassland & 203,062 & 23.4 \\
Pasture & 23,464 & 2.7 \\
Sugar cane & 7 & 0.0 \\
Urban infrastructure & 81 & 0.0 \\
Other non-vegetated areas & 32 & 0.0 \\
Mining & 26 & 0.0 \\
Rivers and lakes & 38,154 & 4.4 \\
Soybean & 31 & 0.0 \\
Other temporary crops & 100 & 0.0 \\
Total & 869,170 & 100.00 \\
\hline
\end{tabular}

Source: Own work (2021). 
Figure 2. Map of land use and cover affected by the wildfires in Poconé in 2020.

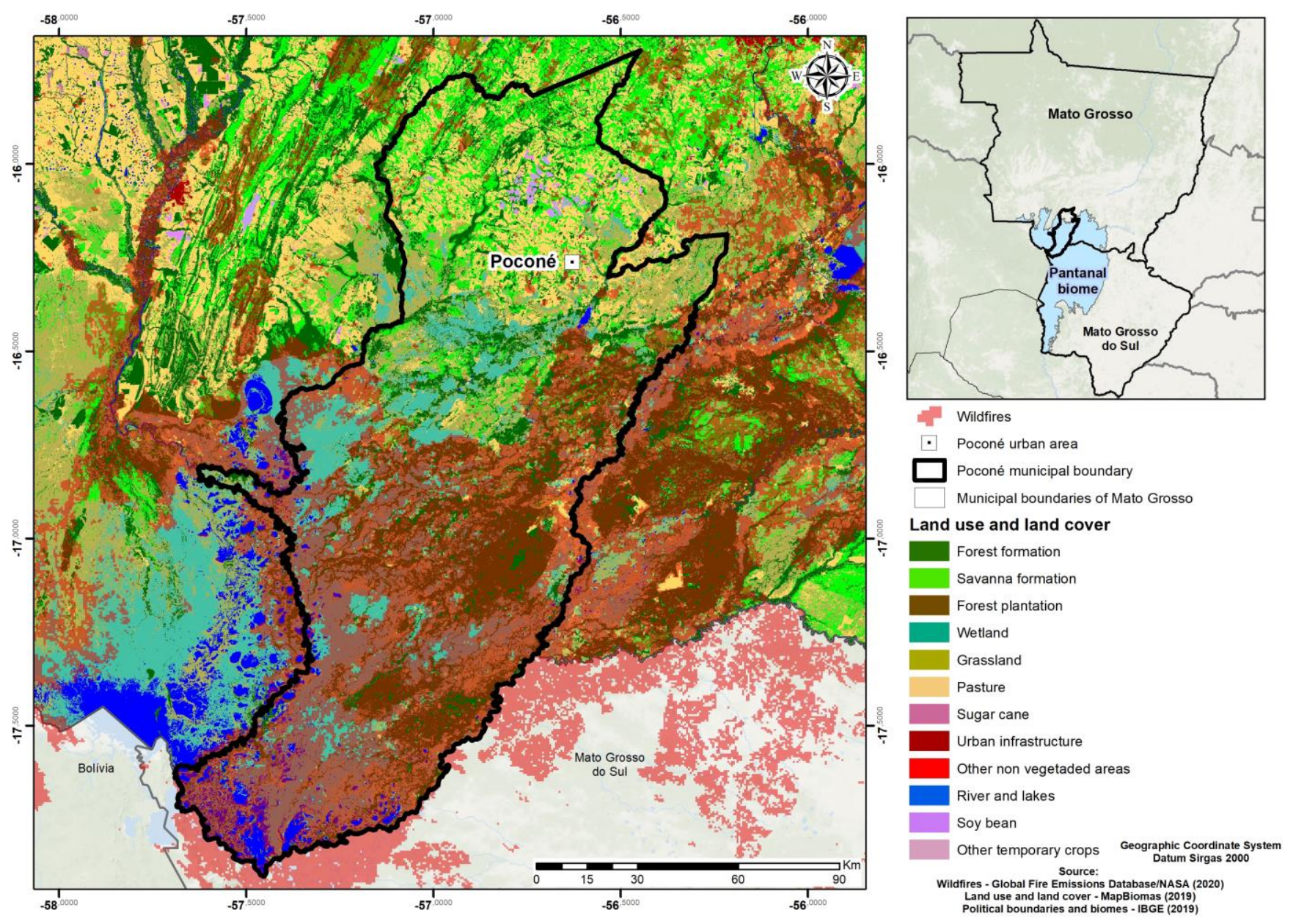

Source: Own work (2021).

\subsection{Land categories}

Of the analyzed land categories, the private rural properties registered in the Rural Environmental Registry (CAR) had the highest wildfire incidence, corresponding to almost half of the mapped wildfires, 49.20\% (427,642 hectares), followed by areas of unregistered private rural properties, with $28 \%$ (242,390 hectares) (Table 3).

Table 3. Data of the land categories affected by wildfires in Poconé in 2020.

\begin{tabular}{ccc}
\hline Land category & Area (hectares) & \% \\
\hline Rural properties in CAR & 427,642 & 16.1 \\
Rural Settlements & 1,198 & 0.8 \\
Conservation units & 196,749 & 76.6 \\
Indigenous lands & 142 & 6.5 \\
Urban area & 49 & \\
Unregistered area & 243,390 & 100.00 \\
Total & 869,170 & \\
\hline
\end{tabular}

Source: Own work (2021).

The conservation units (CU) were the third-most impacted category, with $22.63 \%$ of the burned area, and had 196,749 hectares affected by fire. In 2020, all conservation units that are entirely or partially in the municipality of Poconé were 
impacted by the fire: Pantanal Mato-Grossense National Park (112,393 hectares), Encontro das Águas State Park (50,971 hectares), Dorochê Private Reserve (RPPN) (22,864 hectares), Transpantaneira Park Road (4,841 hectares), Taiamã Ecological Station (4,361 hectares), MT-370 Park Road (1,214 hectares), SESC Pantanal RPPN (60 hectares) and Jubran RPPN (45 hectares) (Figure 3).

Figure 3. Map of the land categories affected by the wildfires in Poconé in 2020.
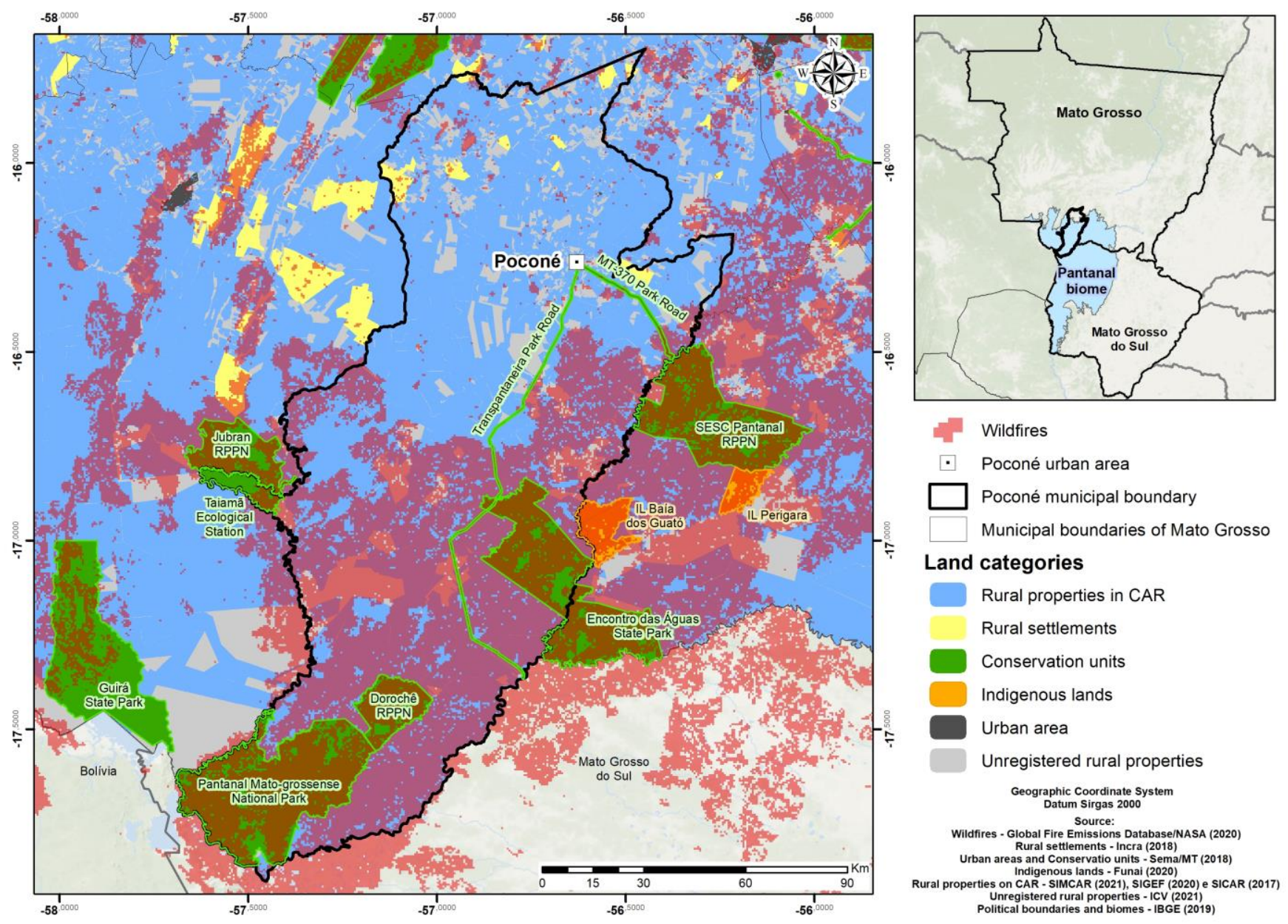

\section{Land categories}

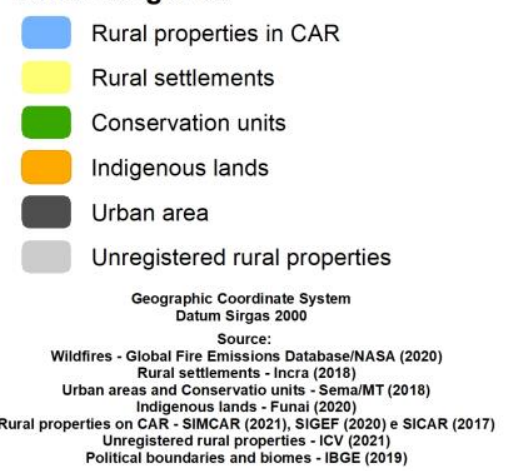

Source: Own work (2021).

\section{Discussion}

By mapping the areas affected by the fire, it was possible to measure accurately the extensive proportions of the Pantanal biome that were burned in Poconé and show that natural formations were the most impacted by the wildfires. Moreover, almost half of the occurrences were identified in rural properties that are registered in CAR.

Regarding the data of wildfire occurrence in 2020 (Tomas et al., 2021; ICV, 2020), the burned areas in the Pantanal of the municipality of Poconé make up $22 \%$ of the total area affected by fire in the whole biome and $40 \%$ of what was burned in the portion of the Pantanal that lies in the state of Mato Grosso. This extension of the wildfires in Pocone highlights the dimension of the impacts of fires on the whole biome, regardless of the macrohabitat characteristics, which explains the high mortality of fauna estimated by Tomas et al. (2021). Most of these animals did not have the opportunity to escape from their original macrohabitats or reach or move to other habitats, causing this collapse in the Pantanal's biodiversity.

In the past decades, global changes have resulted in a wide reduction of biodiversity (McCallum, 2007), which 
directly influences the sustainability of human life on Earth and, consequently, increases the demand for its conservation (Board, 2005). These uncontrolled wildfires threaten Brazil's biodiversity asset, which is protected by the Convention on Biological Diversity and national environmental laws, as well as the long-term commitment to fighting the emission of greenhouse gases within the scope of the Nationally Determined Contribution (NDC), which negatively affects the National Policy of Climate Change (Pletsch et al., 2021).

The natural formations of land cover and use were the most affected by fires in Poconé in 2020. From the data on the type of area that was burned from the mapping available through GFED, when added to the forest and understory areas and recently deforested areas, we have $83.1 \%$ of the affected areas. Considering that among the $16.1 \%$ of savanna and pasture areas there is a portion of savanna, i.e., a natural formation, the percentage of burned natural areas reaches $90 \%$ in Poconé. This result corroborates the area that is found when one analyzes land use and cover from the data of MapBiomas (2020), which showed that, among the burned areas in this municipality, $97.3 \%$ correspond to natural formations, distributed into forests, savannas, grasslands, wetlands, and vegetation in dried-out water bodies.

In a very expressive way, wetlands, i.e., flooded grasslands and swamp areas, were the second-most affected class of native vegetation cover. Naturally, as their name indicates, these areas are characterized by having high humidity during most of the year. However, Marques et al. (2021) observed a decreasing tendency in the soil humidity in general across the whole Pantanal biome in 2020. The comparison between the mean of the historical series and 2020 showed that the variables precipitation, temperature, soil humidity, and evapotranspiration had an atypical behavior. The temporal displacement of precipitation, starting later and ending earlier, with some places indicating a reduction in rainfall, was observed from the south of the Amazon Forest to the Pantanal (Debortoli et al., 2012). Likewise, a reduction in the water mass in the Pantanal was also recorded (Lázaro et al. 2020; MapBiomas, 2021). A study of MapBiomas (2021) indicated that, from 1985 to 2020 , the Pantanal had a $68 \%$ reduction of its water surface, and that Poconé was the fourth municipality in Brazil in the proportion of lost water surface in the past 30 years. The study identified a reduction of 183,717 hectares of water surface between 1990 and 2020 in the municipality. These conditions allowed a large biomass input in these dried-out areas, mainly aquatic macrophytes produced in the environments of bays and floodable areas, which ended up serving as fuel and promoted the 2020 wildfires in the region.

The Pantanal, the largest continuous wetland in the world, has its hydrological cycles connected to the rains that form in the Amazon Forest. Moreover, its geomorphological placement and hydrological characteristics allow the Pantanal to have a regulatory function on the water regime by delaying water drainage (Da Silva et al., 2015; Nunes et al., 2020). The dynamics of flooding, as well as lake depth, time of isolation between ponds, and the distance from the main channel, allow the maintenance of the landscape's complexity and biodiversity (Súarez, Petrere-Júnior \& Catella, 2004; Souza \& Cunha, 2004). Therefore, measurements to reduce the environmental impacts in this region must be encouraged and conducted with the proposal of conserving the changes in water volume and the biodiversity of this dynamic environment (Nunes, Da Silva \& Ferraz, 2017), thus reducing the potential risk of fires.

By analyzing the occurrence of wildfires in the land categories, we observed that rural properties with CAR had almost half of the wildfires (49.2\%), which indicates a great possibility of accountability. The CAR is an obligatory electronic registry for rural properties in the whole country, as stated in the Forest Code. The CAR includes information related to the owner and the rural property, as well as data on the property's hydrography and land use and cover (BRASIL, 2012). The registry is, therefore, an important monitoring tool since, with it, the environmental agencies have access to all necessary data to hold someone accountable for environmental crimes, such as the unauthorized use of fire.

The accountability for the illegal use of fire must occur, but it is also important to actively encourage the adoption of practices that dispense the use of fire to allow a sustainable transition in the product management, as, for example, agroforestry 
and silvopastoral systems. Integrated fire management is also a possible construction, but it must be developed in association with other policy fields, such as those related to the ownership and management of land and according to the climate change agenda (Pivello et al., 2021). According to Garcia et al. (2021), the stakeholders should use the existing traditional, ecological, and scientific knowledge to form a collective strategy with clear, reachable, and measurable goals considering the region's social and ecological context.

The protected areas in Poconé, mainly the conservation units, were also affected by the 2020 wildfires. The burned area of the Pantanal Mato-Grossense National Park represented almost $13 \%$ of the total area impacted by the fire and corresponded to $82 \%$ of the total area of this conservation unit, which is considered a Ramsar Site, core area of the Pantanal's Biosphere Reserve and World Heritage. The Encontro das Águas State Park, which lies between the municipalities of Poconé and Barão de Melgaço, was also greatly impacted. Only in the portion located in Poconé, more than 50 mil hectares were burned in this conservation unit, which had more than $90 \%$ of its area destroyed by fire (ICV, 2020).

These two protected areas are among the most important in Pantanal because they have a huge potential for the conservation of biodiversity and water regime in the region (Polaz, Ferreira \& Pretere Júnior, 2017; Harris et al., 2005). Additionally, these areas are the key for wildlife tourism in this biome, especially birdwatching and, with increasing strength in the past years, observation of jaguars (Tortato \& Izzo, 2017). Wildfires hugely compromise the available habitat for these animals and, consequently, the necessary equilibrium for wildlife tourism to consolidate in the Pantanal, affecting ecological and economic sustainability.

Even though rural settlements, indigenous lands, and the urban area of Poconé had been affected in smaller proportions (respectively $0.14 \%, 0.02 \%$, and $0.01 \%$ in relation to the total burned in the municipality), the impacts on the population that lives in the municipality were immense.

The extreme scenario caused by the strong drought and lack of water was worsened by the uncontrolled wildfires that directly burned whole houses and plantations of riverside and indigenous families, such as the Guató and Bororo ethnic groups.

The socio-economic damage caused by the wildfires includes the loss of productive areas and infrastructures and, directly related to human health, the consequences occur in several levels of severity and spatio-temporal scale that especially affect local communities, firefighters, and more vulnerable groups such as the elderly, children and pregnant women (Fiocruz, 2020). The technical note prepared by Fiocruz (2020) observed that the particulate matter and toxic gases generated by vegetation burn can reach long distances, with the capacity of reaching populations hundreds of kilometers from the wildfires. Particulate matter has great inflammatory potential and is the entrance for respiratory infections as shown in another study by Fiocruz (2019) in the areas that were the most affected by fire in the Amazon region in 2019. The results showed that, in these regions, the number of children hospitalized with respiratory problems doubled, leading to a cost overrun of $\mathrm{R} \$ 1.5$ million to the National Health Service (SUS).

\section{Final Considerations}

In the face of this scenario, we see an urgency for actions of prevention and mitigation of the occurrence of wildfires, which should be combined and implemented in an integrated way by several actors. It is also very important to demand the position of the federal and state governments, which are managers of the agencies that respond to the planning of wildfire prevention and fight.

The actions include especially the need for supervising, investigating, and making accountable those that caused the 2020 wildfires, including educational ways by indicating zero tolerance for the use of unauthorized fire. For this purpose, we suggest the combination of the use of CAR data with the mapping of the areas affected by fire, as conducted in this study, to make those that caused the fire accountable, but also to build community agreements and action plans for wildfire prevention 
and fight.

It is also necessary to keep strengthening the firefighting teams to reduce the response time at the start of wildfires. The faster the action, the smaller the damages that the fire will cause. The preventive actions have to be increasingly present in the face of a scenario of climate crisis, intense drought, and reduced water surface in this region. We recommend adopting risk maps, systems of wildfire alert, and a program of integrated fire management in total synergy with the managers and local communities. In this respect, we also recommend the reduction of top-down decision-making through better structuring of the environmental agencies in this region, thus strengthening the local mobilization and social participation. This can encourage land users to adopt techniques that allow a transition toward more sustainable land uses that dispense the use of fire.

Finally, it is very important to develop other works like this one, for other municipalities and regions affected by fires, in order to gather information that contributes to support, in an emergency, the population and impacted vulnerable social groups, as well as to help recover the affected areas after the wildfires.

\section{Acknowledgments}

We thank to the Mato Grosso Research Support Foundation for funding this research, within the scope Project "Ecological, economic and cultural corridor of the Paraguay River"(Grant Number FAPEMAT.0308817/2017), in contribution $\mathrm{n}^{\circ}$ 15. We also thank the National Council for Scientific and Technological Development (CNPq) for the productivity research fellowship (Carolina J. da Silva), within the scope of the Long Duration Ecological Research Project (PELD). We are grateful to the Mato Grosso State University and the Environmental Science Graduate Program, the Bionorte Network Graduate Program, the Pantanal Research Center in Limnology, Biodiversity and Ethnobiology, and to the Centro de Vida Institute (ICV) for the partnership to the development this work.

\section{References}

Andela, N., Morton, D. C., Giglio, L., Paugam, R., Chen, Y., Hantson, S., van der Werf, G. R., \& Randerson, J. T. (2019). The Global Fire Atlas of individual fire size, duration, speed, and direction. Earth System Science Data, 11, 529-552.

Aragão, L. E. O. C., Anderson, L. O., Fonseca, M. G., et al. (2018). 21st Century drought-related fires counteract the decline of Amazon deforestation carbon emissions. Nature Communications, 9, 536.

ArcGIS. (2020). Software Version 10.8. Environmental Systems Research Institute, Inc. Redlands, CA.

Board, M. A. (2005). Millennium Ecosystem Assessment - Ecosystems and Human Well-Being. Island Press.

BRASIL. (2012). Lei n. 12.651, de 25 de maio de 2012. Dispõe sobre a proteção da vegetação nativa e dá outras providências. Diário Oficial da União, Brasília, DF, Ano CXLIX, n. 102.

Burin, P. C., \& Fuentes, L. F. G. (2015). Uso do fogo como alternativa no controle de plantas daninhas. Revista Electrónica de Veterinaria, $16(8)$, 1-13.

Da Silva, C. J., Silva Souza, K. N., Ikeda-Castrillon, S. K., Lopes, C. R. A. S., Silva Nunes, J. R., Carniello, M. A., Mariotti, P. R., Lazaro, W. L., Morini, A., Zago, B. W., Façanha, C. L., Albernaz-Silveira, R., Loureiro, E., Viana, I. G., Oliveira, R. F., Alves da Cruza, W. J., De Arruda, J. C., Sander, N. L., Freitas Junior, D. S., Pinto, V. R., De Lima, A. C., \& Jongman, R. H. G. (2015). Biodiversity and its drivers and pressures of change in the wetlands of the Upper Paraguay-Guaporé Ecotone, Mato Grosso (Brazil). Land Use Policy, 47, 163-178.

Da Silva, C. J., \& Esteves, F. A. (1995). Dinâmica das características limnológicas das baías Porto de Fora e Acurizal (Pantanal de Mato Grosso) em função da variação do nível da água. Oecologia Brasiliensis. 47-60.

Debortoli, N., Dubreuil, V., Delahaye, F., \& Rodrigues Filho, S. (2012). Análise temporal do período chuvoso na Amazônia meridional brasileira (1971-2010). Revista Geonorte, 3(8), 382-394.

Fiocruz. (2020). Covid-19 e queimadas na Amazônia Legal e Pantanal: aspectos cumulativos e vulnerabilidades. Nota técnica. Observatório de Clima e Saúde. Instituto de Comunicação e Informação Científica e Tecnológica em Saúde (ICICT). Fundação Oswaldo Cruz (Fiocruz). 1-17.

Fiocruz. (2019). Queimadas na Amazônia e seus impactos na saúde: a incidência de doenças respiratórias no sul da Amazônia aumentou significativamente nos últimos meses. $3^{\circ}$ informe técnico. Observatório de Clima e Saúde. Instituto de Comunicação e Informação Científica e Tecnológica em Saúde (ICICT). Fundação Oswaldo Cruz (Fiocruz). 1-15. 
Fonseca-Morello, T., Ramos, R., Steil, L., Parry, L., Barlow, J., Markusson, N., \& Ferreira, A. (2017). Fires in Brazilian Amazon: Why does policy have a limited impact? Ambiente \& Sociedade, 20(04), 19-38.

Garcia, L. C., Szabo, J. K., Roque, F. O., Pereira, A. M. M., Nunes da Cunha, C., Damasceno-Júnior, G. A., Morato, R. G., Tomas, W. M., Libonati, R., \& Ribeiro, D. B. (2021). Record-breaking wildfires in the world's largest continuous tropical wetland: Integrative fire management is urgently needed for both biodiversity and humans. Journal of Environmental Management, 293, 112870.

Harris, M. B., Tomas, W., Mourão, G., Silva, C. J., Guimarães, E., Sonoda, F., \& Fachim, E. (2005). Safeguarding the Pantanal Wetlands: Threats and Conservation Initiatives. Conservation Biology, 19(03), 714-720.

IBAMA. (2003). Plano de Manejo do Parque Nacional do Pantanal Mato-grossense. https://www.icmbio.gov.br/portal/images/stories/imgs-unidadescoservacao/parna_matogrossensee.pdf

IBGE. (2012). Manual técnico da vegetação brasileira. (2a ed.). Manuais técnicos em geociências. IBGE. 1-271.

IBGE. (2019). Biomas e sistema costeiro-marinho do Brasil: compatível com a escala 1:250.000. Série Relatórios Metodológicos. Coordenação de Recursos Naturais e Estudos Ambientais. IBGE. 1-168.

ICV. (2020). Balanço dos incêndios em Mato Grosso em 2020. Nota técnica. Instituto Centro de Vida: ICV. 1-9.

Lázaro, W. L., Oliveira-Júnior, E. S., Da Silva, C. J., Castrillon, S. K. I., \& Muniz, C. C. (2020). Climate change reflected in one of the largest wetlands in the world: an overview of the Northern Pantanal water regime. Acta Limnologica Brasiliensia, 32(104), 1-8.

Libonati, R., Pereira, J. M. C., Da Camara, C. C., Peres, L. F., Oom, D., Rodrigues, J. A., Santos, F. L. M., Trigo, R. M., Gouveira, C. M. P., Machado-Silva, F., Enrich-Prast, A., \& Silva, J. M. N. (2021). Twenty-first century droughts have not increasingly exacerbated fire season severity in the Brazilian Amazon. Scientific Reports, 11, 4400.

MapBiomas. (2020). MapBiomas - Coleção 5 da Série Anual de Mapas de Uso e Cobertura da Terra do Brasil. https://mapbiomas.org/download

MapBiomas. (2021). A dinâmica da superfície de água do território brasileiro: MapBiomas Água. p $16 . \quad$ https://mapbiomas-brsite.s3.amazonaws.com/MapBiomas_A\%CC\%81gua_Agosto_2021_22082021_OK_v2.pdf

Marques, J. F., Alves, M. B., Silveira, C. F., Amaral e Silva, A., Silva, T. A., Santos, V. J., \& Calijuri, M. L. (2021). Fires dynamics in the Pantanal: Impacts of anthropogenic activities and climate change. Journal of Environmental Management, 299, 113586.

McCallum, M. L. (2007). Amphibian Decline or Extinction? Current Declines Dwarf Background Extinction Rate. Journal of Herpetology, 41(3), 483-491.

Nunes, J. R. S., Da Silva, C. J., \& Ferraz, L. (2017). Mato Grosso e seus biomas: Biodiversidade, Desafios Sócio Ambientais, Unidades de Conservação Iniciativas de Políticas Públicas e Privadas para a Conservação. Revista Gestão Universitária, 07, 1-28.

Nunes, J. R. S., Da Silva, C. J., Ikeda-Castrillon, S. K., \& Sander, N. L. (2020). Mudança na composição de assembleia de aves aquáticas associadas com mudanças no nível de água em uma Zona de Transição Terrestre Aquática no Pantanal de Mato Grosso, Brasil. Research, Society and Development, 9(10), e4479108555.

Oliva, P., \& Schroeder, W. (2015). Assessment of VIIRS 375m active fire detection product for direct burned area mapping. Remote Sensing of Environment, $160,144-155$.

Oliveira, A. D., \& Zibetti, M. L. T. (2016). Puruborá: analisando a história, o "ressurgimento" e a resistência de um povo indígena da Amazônia. Espaço Ameríndio, 10(01), 103-144.

Pivello, V. R., Vieira, I., Christianini, A. V., Ribeiro, D. B., Menezes, L. S., Berlinck, C. N., Melo, F. P. L., Marengo, J. A., Tornquist, C. G., Tomas, W. M., \& Overbecket, G. E. (2021). Understanding Brazil's catastrophic fires: causes, consequences and policy needed to prevent future tragedies. Perspectives in Ecology and Conservation, 19(03), 233-255.

Pletsch, M. A. J. S., Silva Junior, C. H. L., Penha, T. V., Korting, T. S., Silva, M. E. S., Pereira, G., Anderson, L. O., \& Aragão, L. E. O. C. (2021). The 2020 Brazilian Pantanal fires. Annals of the Brazilian Academy of Sciences, 93(3), 1-3.

Polaz, C. N. M., Ferreira, F. C., \& Petrere Júnior, M. (2017). The protected areas system in Brazil as a baseline condition for wetlands management and fish conservancy: the example of the Pantanal National Park. Neotropical Ichthyology, 15(3), 1-13.

Rebellato, L., \& Nunes da Cunha, C. (2005). Efeito do "fluxo sazonal mínimo da inundação" sobre a composição e estrutura de um campo inundável no Pantanal de Poconé, MT, Brasil. Acta Botanica Brasilica, 19, 789-799.

Santos, F. L. M., Libonati, R., Peres, L. F., Pereira, A. A., Narcizo, L. C., Rodrigues, J. A., Oom, D., Pereira, J. M. C., Schroeder, W., \& Setzer, A. W. (2020). Assessing VIIRS capabilities to improve burned area mapping over the Brazilian Cerrado. International Journal of Remote Sensing, 41(21), $8300-8327$.

Silva, S. S., I. S. de Oliveira, T. F. Morello, L. O. Anderson, A. Karlokoski, P. M. Brando, A. W. F. de Melo, J. G. da Costa, F. S. C. Souza, I. S. de Souza, E. N. de Souza, M. P. Pereira, M. R. N. de Almeida, A. Alencar, L. E. O. C. Aragão, I. F. Brown, P. M. L. A. Graça \& P. M. Fearnside. (2021). Burning in southwestern Brazilian Amazonia, 2016-2019. Journal of Environmental Management, 286, 1-26.

Souza Jr., C. M., et. al. (2020). Reconstructing Three Decades of Land Use and Land Cover Changes in Brazilian Biomes with Landsat Archive and Earth Engine. Remote Sensing, 12(17), 1-27.

Souza, C. A., \& Cunha, S. B. (2004). Dinâmica das águas no Pantanal Mato-Grossense Pantanal. Mato-grossense. Revista Ação Ambiental, 06(26). 
Research, Society and Development, v. 10, n. 15, e08101522619, 2021

(CC BY 4.0) | ISSN 2525-3409 | DOI: http://dx.doi.org/10.33448/rsd-v10i15.22619

Súarez, Y. R., Petrere-Júnior, M., \& Catella, A. C. (2004). Factors regulating diversity and abundance of fish communities in Pantanal lagoons, Brazil. Fisheries Management and Ecology, 11(1), 45-50.

Tedim, F., \& Leone, V. (2020). The Dilemma of Wildfire Definition: What It Reveals and What It Implies. Frontiers in Forests and Global Change, $3(553116), 1-14$.

Tomas, W., et al. (2021). Counting the dead: 17 million vertebrates directly killed by the 2020's wildfires in the Pantanal wetland, Brazil. Research Square: Scientific reports, 10.21203/rs.3.rs-859794/v1, 1-16.

Tortato, F. R., Izzo, T. J., Hoogesteijn, R., \& Peres, C. A. The numbers of the beast: Valuation of jaguar (Panthera onca) tourism and cattle depredation in the Brazilian Pantanal. Global Ecology and Conservation, 11, 106-114.

Tortato, F. R., \& Izzo, T. J. Advances and barriers to the development of jaguar-tourism in the Brazilian Pantanal. Perspectives in Ecology and Conservation, 15(1), 61-63. 